\title{
The relationship between somatic sense perception levels and comorbid psychiatric diseases in chronic pain patients
}

\author{
Kronik ağrı hastalarında bedensel duyumları algılama düzeyi ve psikiyatrik \\ komorbidite arasındaki ilişki
}

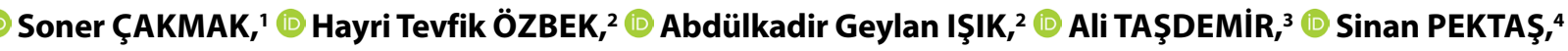 \\ (D) Hakkı ÜNLÜGENÇ, 5 @ Lut TAMAM, ${ }^{10}$ Mehmet Emin DEMIRKOL'
}

\begin{abstract}
Summary
Objectives: The purpose of the study was to evaluate any comorbid psychiatric disorders in patients with chronic pain and to examine the effects of sociodemographic details and the level of somatic sense perception on the severity of these diseases. Methods: In this study, 51 chronic pain patients were evaluated in a consultation with a psychiatrist. Sociodemographic characteristics of the patients, such as age, gender, education level, and marital status were recorded, and Structured Clinical Interview for DSM-IV results were assessed. The patients' chronic pains were classified as idiopathic or secondary to organic etiology. In addition, the Symptom Checklist-90, Somatosensory Amplification Scale (SSAS), Hamilton Depression Rating Scale, and the Hamilton Anxiety Scale (HAM-A) were used.

Results: The incidence of psychiatric disorders in chronic pain patients was found to be $74.5 \%$. Somatoform disorders were the most frequently diagnosed, at $37.3 \%$. The rate of depressive and anxiety disorders was, respectively, $29.4 \%$ and $23.5 \%$. Comorbid anxiety scores $(p=0.019)$ and SSAS scores $(p=0.046)$ were significantly higher in chronic pain patients with a somatoform disorder. HAM-A scores were found to be significantly higher in patients with depression $(p=0.004)$. A positive and linear relationship was determined between the SSAS score and depression, anxiety, and the severity of mental symptoms.

Conclusion: Structured or semi-structured interviews can be performed in pain polyclinics or psychiatric outpatient clinics to determine the level of perception of somatic sensations. This could be beneficial in the treatment of chronic pain and comorbid psychiatric disorders.
\end{abstract}

Keywords: Chronic pain; comorbidity; psychiatry; somatic sense perception.

Özet

Amaç: Biz bu çalışmada kronik ağrı hastalarında komorbid psikiyatrik hastalıkları araştırdık ve bu hastalıkların şiddeti üzerinde hastaların bedensel duyumları algılama düzeylerinin ve sosyodemografik özelliklerinin etkilerini inceledik.

Gereç ve Yöntem: Bu çalışmada 51 kronik ağrı hastası konsültasyon yoluyla psikiyatri hekimi tarafından değerlendirilmiştir. Katılımcılara DSM-IV için yapılandırımış klinik görüşme (SCID I) uygulanmış, yaş, cinsiyet, medeni durum, eğitim düzeyi gibi sosyodemografik verileri alınarak, ağı etiyolojileri belirlenmiş ve ağı hastaları idiopatik ve organik etiyolojiye sekonder kronik ağrı hastaları olarak sınıflandırılmıştır. Katılımcılara Ruhsal Belirti Tarama Listesi (SCL-90R), Bedensel Duyumları Algılama Ölçeği (SSAS), Hamilton Depresyon Derecelendirme Ölçeği (HAM-D), Hamilton Anksiyete Dercelendirme Ölçeği (HAM-A) uygulanmıştır. Bulgular: Kronik ağrı hastalarında psikiyatrik bozuklukların yaygınlığı \%74.5 olarak bulunmuştur. Somatoform bozukluklar \%37.3 ile en sık teşhis edilen bozukluk olup, depresif bozukluklar \%29.4, anksiyete bozuklukları \%23.5 oranında bulunmuştur. Somatoform bozukluk saptanan kronik ağrı hastalarında komorbid anksiyete puanları $(p=0.019)$ ve SSAS puanları $(p=0.046)$ anlamlı olarak yüksek bulunmuştur. Depresyon tanısı alan katılımcılarda HAM-A puanları anlamlı olarak yüksek bulunmuştur $(p=0.004)$. SSAS puanları ile hastalardaki depresyon, anksiyete ve ruhsal belirti şiddeti arasında pozitif bir ilişki olduğu saptanmıştır.

Sonuç: Bedensel duyumları algılama düzeylerini belirleme ile ilgili olarak ağrı polikliniklerinde veya psikiyatri polikliniklerinde yapılandııılmış veya yarı yapılandırılmış görüşmelerin uygulanması bu hastalarda kronik ağrının ve komorbid psikiyatrik rahatsızlıkların tedavisi ve prognozunda yarar sağlayacaktır.

Anahtar sözcükler: Kronik ağrl; komorbidite; bedensel duyumlar; psikiyatri.

\footnotetext{
'Department of Psychiatry, Çukurova University Faculty of Medicine, Adana, Turkey

${ }^{2}$ Department of Algologia, Çukurova University Faculty of Medicine, Adana, Turkey

${ }^{3}$ Department of Psychiatry, Niğde State Hospital, Niğde, Turkey

${ }^{4}$ Department of Anesthesia, Van Research Hospital, Van, Turkey

${ }^{5}$ Department of Anesthesia, Çukurova University Faculty of Medicine, Adana, Turkey

Correspondence: Dr. Soner Çakmak. Çukurova Üniversitesi Tıp Fakültesi, Ruh Sağıı̆ı ve Hastalıkları Anabilim Dalı, Adana, Turkey.

Phone: +90 - 322 - 3386060 / 3204 e-mail: drsoncak@hotmail.com

(c) 2019 Turkish Society of Algology

Submitted (Başvuru tarihi) 03.09.2018 Accepted after revision (Düzeltme sonrası kabul tarihi) 15.05.2019 Available online date (Online yayımlanma tarihi) 29.05.2019 


\section{Introduction}

It has been known that psychiatric problems significantly affect somatic disorders, make treatment difficult, and affect the prognosis negatively. Patients who were diagnosed with appropriate methods could help to understand the complex relationship between psychiatric disorders and chronic pain. Psychiatric structured and semi-structured tests are rarely used in patients with chronic pain. ${ }^{[1]}$ Despite clinical importance, psychiatric disorders are often ignored in pain clinics. In recent years, the incidence of psychiatric comorbidity has increased in patients who are referred to tertiary care pain clinics. Therefore, it is thought that chronic pain may also be the effect of common psychiatric diseases. ${ }^{[2]}$

In many studies, the rates of psychiatric disorders in patients with chronic pain were found higher than the general population. ${ }^{[3-5]}$ Chronic pain is correlated with psychiatric disorders. Reactive psychological symptoms such as depression and anxiety can play an important role in the exacerbation of pain perception. ${ }^{[6]}$ There is evidence that depression, anxiety and emotional distress symptoms in chronic pain patients contribute strongly to sustained and long-term outcomes such as physical disability, job disability, health care costs, mortality and suicide (more powerful than pain intensity in many studies). ${ }^{[7-12]}$ Studies investigating the relation between chronic pain and psychiatric morbidity were generally related to depression. Depression is the most frequently reported disorder in patients with chronic pain. ${ }^{[2]}$ In these early studies, it was stated that the depression rates in patients with chronic pain was increasing with advanced ages and lower education levels..$^{[13]}$ It was also pointed that there was a difference between genders and it was suggested that depression was seen more in women. ${ }^{[14]}$ In order to explain these findings, interpretations were made as women had lower pain thresholds, that their pain beliefs differed from men, and that they experienced depression as a reaction to pain. ${ }^{[15]}$ However, recent studies do not support all these relations. Wijeratne et al. have compared the depression rates between young ( $<65$ years) and elder ( 65 years and older) patients who came to the chronic pain clinic. ${ }^{[16]}$ They have not found a link between age and depression. Furthermore, there was no relationship between major depressive disorder and gender and duration of pain in the same study.
[16] Similarly, Geerlings et al. have found that age is not an effect on depression in pain patients. ${ }^{[17]}$

Anxiety can also be expected to be seen as a common psychiatric symptom in patients with chronic pain. In some studies it has been suggested that there is a relationship between pain intensity and fear; pain catastrophy and anxiety, in chronic pain patients. ${ }^{[18]}$

In a study, anxiety disorders were found $35 \%$ in patients with chronic pain and $17 \%$ in healthy individuals. Generalized anxiety disorder is the most common psychiatric disorder in primary care. Patients often complain about pain and somatic symptoms more than anxiety; therefore, diagnosis is difficult and patients cannot be treated completely. ${ }^{[19]}$ In chronic pain patients, the number of studies on anxiety disorders is less than those associated with depression. However, there is growing evidence that the pharmacological treatment of anxiety can significantly decrease the pain. ${ }^{[20]}$

Somatoform pain disorder among somatoform disorders is a common psychiatric disorder in patients with chronic pain. In a study with 89 patients in China, the incidence of somatoform disorders in patients with chronic pain was found as $33.7 \% .{ }^{[21]}$ Polatin et al. and Dersh et al. have found that depressive and somatoform disorders are the most common psychiatric disorders in chronic pain patients, similar to those in China. ${ }^{[21-23]}$ The association of chronic pain with depression and anxiety may become permanent over time. ${ }^{[24,25]}$

The purpose of this study was to find the frequency of psychiatric comorbidities (depression, anxiety and somatoform disorders) in patients who applied to the pain outpatient clinic and had psychiatric consultation; and to determine whether these disorders were associated with pain related factors such as sociodemographic characteristics, pain etiology and exaggeration of somatic sensations.

\section{Material and Method}

Fifty-one patients who were admitted to Cukurova University School of Medicine, pain outpatient clinic between August 2013-March 2014, who had chronic pain complaints and who were consulted to the psy- 
chiatrist by pain physician for possible psychiatric comorbidities. Fifty-five patients were interviewed and four patients who did not approve participation in the study were excluded from the study and 51 were included in the study. Participants' psychiatric diagnostic evaluation was performed after medical and psychiatric history and sociodemographic features were noted. The data were recorded in a form. Approval of the local ethics committee and written consent of the patients were taken. Patients who were 18 years of age or older and had chronic pain complaints for at least one year were included in the study. Patients with mental retardation, organic mental problems and dementia (those with a Minimental test score lower than 24) were excluded from the study.

Sociodemographic data such as age, gender, marital status, educational level were taken after the evaluation of the pain clinic physicians. Participants' chronic pains were classified as idiopathic and secondary to organic etiology according to the information given by the pain physician.

The study population was small, which restricts the power of statistical analyzes. The study group consisted of patients continuing to the pain outpatient clinic, so there was a bias in patient selection. Our study was conducted with patients with different types of pain. However, the results are still not universal for all chronic pain patients.

Sociodemography data form; It is the data form prepared by us that records participants' age, gender, marital status and educational level.

SCL-90-R Symptom Checklist; The SCL-90-R Symptom Screening List is defined as a psychiatric symptom screening tool that identifies the level of stress experienced by the individual. This test was developed by Derogatis, in 1997. ${ }^{[26]}$ In 1991, the scale was adapted to Turkish by İhsan Dağ. ${ }^{[27]}$ Reliability and validity analysisensured that the scale was applicable in Turkey. SCL-90-R has 90 questions and 9 different symptom groups. The average symptom score is obtained by the scores of 9 sub-symptom groups (Somatization, Obsessive-Compulsive, Interpersonal Sensitivity, Depression, Anxiety, Hostility, Phobic anxiety, Paranoid thought and Psychotism) and the score of additional scale. There is 5 choices in every question as "None, very few, moderate, high, very high " and scored with 0-1-2-3-4 respectively. Then, three general points are calculated from the scale. Positive Symptom Index (PSI) is obtained by summing the raw numbers of the other items except those that are 'none' selected. The Positive Symptom Distress Index (PSDI) is obtained by dividing the sum of the grading points of the items except the ones marked as 'none' to the PSI. The Global Symptom In$\operatorname{dex}(\mathrm{GSI})$ score is obtained by dividing the total score of the test to the all items except the ones left blank. This score points to the increase in distress experienced due to psychiatric symptoms and it is accepted as the most reliable parameter of the scale. When it is used for survey purposes, cut-off score of GSI is often taken as 1 point. For the subscales, the value obtained by dividing the score obtained from the sum of all the questions constituting that subscale by the number of questions is used. As a surveillance scale, SCL-90-R, is not used for diagnosis, but numerical values above 1 are considered to be higher than the general average. The general reliability of the SCL-90 scale that was applied to the participants was found high $(a=0.971)$.

Hamilton Depression Rating Scale (HAM-D):The scale developed by Hamilton aims to measure the severity of depressive symptoms. ${ }^{[28]}$ The scale used by the physicians contain scores from 0 to 4 for each of the 17 depressive manifestations. Turkish validity and reliability study was conducted by Akdemir et al. in 1996. ${ }^{[29]}$

Hamilton Anxiety Rating Scale (HAM-A):The scale developed by Hamilton in 1959 was prepared to determine the level of anxiety and symptom distribution, and to measure the changes in the intensity of symptoms. ${ }^{[30]}$ The validity and reliability study of the Turkish version was made by Yazıcı et al. in 1998. ${ }^{[31]}$ At this scale of 14 items, the practitioner scores from 0 to 4 for each item. Score range is $0-56.1,2,3,5$ and $6^{\text {th }}$ items are calculated as psychic subscores and 4 , $7,8,9,10,11,12,13^{\text {rd }}$ items are calculated as somatic subscores.

Somatosensory Amplification Scale (SSAS): The scale was developed by Barsky et al. ${ }^{[32]}$ Turkish validity and 
reliability studies were conducted by Guleç et al. ${ }^{[33]}$ It is an assessment scale that measures how patients experience somatic symptoms and their susceptibility to somatization. In addition to those with psychiatric disorders, it can also be used in patients with any medical condition or in healthy population. 10 items in the questionnaire are scored on a five-point Likert scale. Its a self report scale. Participants using the scale are asked to score each question between 1 (not at all) and 5 (extremely). The total score is between 10-50. The cut-off score of the scale is not calculated. This scale is used in comparative studies. In the internal consistency study of the scale, Coronbach alpha values were ranged from $0.62-0.76$. The total score of the scale showed adequate test-retest consistency $(r=0.73)$.

\section{Statistical Analysis}

All statistical evaluations of our study were conducted with IBM The Statistical Package for Social Sciences (SPSS) Statistics v20 (IBM Corporation, New York, United States). Categorical variables were compared with Chi-square test, frequencies and ratios, and Fisher's exact Chi-square test was applied where necessary. The averages of the continuous variables of the two groups were compared with Student $T$ test. Pearson Correlation test was used for correlation of categorical variables. Descriptive statistics on sociodemographic data are also presented.

\section{Results}

The socio-demographic properties of the patients were summarized in the table (Table 1). $72.5 \%$ of the patients were female and $27.5 \%$ were male. $81.2 \%$ of the patients were married and $11.8 \%$ were single. $45.1 \%$ of the patients had primary education or lower, and $54.9 \%$ had secondary education or higher education levels. The mean age was $41.1 \pm 11.4$ for women and $38.2 \pm 10.3$ for men. The mean age of all patients was $40.3 \pm 11.1$ (Table 1).

Participants' pain types and pain etiologies were assessed with patients history and pain outpatient clinic records (Table 2). Chronical headache was present in 13 of the patients (organic etiology was not defined in 7), chronic back and neck pain was present in 9 of the patients (organic etiology was not defined in 2), extremity pain was present in 8 of the patients (organic etiology was not defined in 5), pelvic and abdominal pain was present in 3 of the patients (organic etiology was not defined in 1), common musculoskeletal pain was present in 18 of the patients (organic etiology was not defined in 12, 6 of them were diagnosed with fibromyalgia). Organic etiology was defined in 24 (47\%) of the patients and organic etiology was not defined in 27 (53\%) patients. Localized pain was defined in 33 (64.7\%) of the patients and common musculoskeletal pain was defined in 18 (35.3\%) of the patients (Table 2 ).

All patients were assessed with SCID I by an experienced psychiatrist and comorbid psychiatric diseases were investigated. The prevalence of current psychiatric disorders was found as $\mathbf{7 4 . 5 \%}$. Somatoform disorders are the most frequently diagnosed cases (37.3\%).The rates of depressive and anxiety disorders were $29.4 \%$ and $23.5 \%$, respectively (Table 3 ).

Table 1. Sociodemographic characteristics of the patients

\begin{tabular}{|c|c|c|c|c|c|c|}
\hline & \multicolumn{2}{|c|}{$\begin{array}{c}\text { Female }(n=37) \\
(72.5 \%)\end{array}$} & \multicolumn{2}{|c|}{$\begin{array}{c}\text { Male }(n=14) \\
(27.5 \%)\end{array}$} & \multicolumn{2}{|c|}{$\begin{array}{c}\text { Total }(n=51) \\
(\%)\end{array}$} \\
\hline & $\mathbf{n}$ & $\%$ & $\mathbf{n}$ & $\%$ & $\mathbf{n}$ & $\%$ \\
\hline \multicolumn{7}{|l|}{ Martial status } \\
\hline Married & 34 & 91.9 & 11 & 78.6 & 45 & 81.2 \\
\hline Single & 3 & 8.1 & 3 & 21.4 & 6 & 11.8 \\
\hline \multicolumn{7}{|l|}{ Education status } \\
\hline Primary education and lower & 16 & 43.2 & 7 & 50 & 23 & 45.1 \\
\hline Secondary education and higher & 23 & 56.8 & 7 & 50 & 28 & 54.9 \\
\hline Age $($ Mean $\pm S D)$ & \multicolumn{2}{|c|}{$41.1 \pm 11.4$} & \multicolumn{2}{|c|}{$38.2 \pm 10.3$} & \multicolumn{2}{|c|}{$40.3 \pm 11.1$} \\
\hline
\end{tabular}

$\mathrm{n}$ : Number of patients; SD: Standart deviation. 
Table 2. Type, localization and etiological properties of the pain

\begin{tabular}{|c|c|c|c|c|c|c|c|}
\hline \multicolumn{2}{|l|}{ Pain type } & \multicolumn{2}{|l|}{ Organic etiology (+) } & \multicolumn{2}{|c|}{$\begin{array}{c}\text { Organic } \\
\text { etiology (-) }\end{array}$} & \multicolumn{2}{|c|}{ Total } \\
\hline & & $\mathbf{n}$ & $\%$ & $\mathbf{n}$ & $\%$ & $\mathbf{n}$ & $\%$ \\
\hline Head and face pain & $\frac{.5}{\frac{1}{2}}$ & $\begin{array}{l}6 \\
2 \text { after spinal anesthesia, } \\
1 \text { trigeminal neuralgia, } \\
1 \text { after jaw surgery, } \\
1 \text { tuberculous meningitis, } \\
1 \text { migraine }\end{array}$ & 25 & 7 & 25.9 & 13 & 25.5 \\
\hline Neck and low back pain & 욜 & $\begin{array}{l}7 \\
6 \text { vertebral hernie, } \\
1 \text { ankylosing spondylitis }\end{array}$ & 29.2 & 2 & 7.4 & 9 & 17.7 \\
\hline Extremity pain & & $\begin{array}{l}3 \\
2 \text { after epidural anesthesia, } \\
1 \text { alcoholic neuropathy }\end{array}$ & 12.5 & 5 & 18.5 & 8 & 15.7 \\
\hline \multirow[t]{2}{*}{ Pelvicand abdominal pain } & & 2 & 8.3 & 1 & 3.7 & 3 & 5.8 \\
\hline & & 2 after orchitis and testis op & ation & & & & \\
\hline \multirow{2}{*}{\multicolumn{2}{|c|}{ Common musculoskeletal pain }} & 6 & 25 & 12 & 44.4 & 18 & 35.3 \\
\hline & & 6 fibromyalgia & & & & & \\
\hline Total & & 24 & 47 & 27 & 53 & 51 & 100 \\
\hline
\end{tabular}

$\mathrm{n}$ : Number of patients.

Table 3. Psychiatric diagnoses identified with SCID I assessment

\begin{tabular}{lcc}
\hline & $\mathbf{n = 5 1}$ & \% \\
\hline Anxiety disorders & 12 & 23.5 \\
Somatoform disorders & 19 & 37.3 \\
Depressive disorder & 15 & 29.4 \\
Psychiatric diagnoses (total) & 38 & $\mathbf{7 4 . 5}$ \\
\hline
\end{tabular}

SCID I: Structured Clinical Interview for DSM-IV; n: Number of patients.

Participants chronic pains were classified as idiopathic and secondary to organic etiology according presence or absence of organic etiology of the pain. For both groups, Symptom Check List-90 (SCL-90R), Somatosensory Amplification Scale (SSAS), Hamilton Depression Rating Scale (HAM-D) and Hamilton Anxiety Scale (HAM-A) tests were used and scores of the groups were compared. (Table 4). There was no significant difference between SCL 90, SSAS, HAM-D and HAM-A scores in terms of presence or absence of organic etiology of the pain (Table 4).

Sociodemographic variables, SCLR 90, SSAS, HAM-
A, HAM-D, were compared between the patients with and without psychiatric diagnosis (Table 5). There was no significant difference between these two groups in terms of gender, marital status, education status and age. However, it was found that the scores of HAM-D, HAM-A, SSAS and SCL-90 were significantly higher in the chronic pain patients who had psychiatric diagnosis. This significant difference has increased the reliability of the semi-structured DSM IV-directed SCID I diagnostic evaluation in our study (Table 5).

Chronic pain patients were divided into two groups in terms of presence or absence of comorbid somatoform disorders. HAM-A, HAM-D, SSAS scale were assessed to determine whether there was any significant difference between these two groups. Comorbid anxiety scores and SSAS scores were significantly higher in chronic pain patients who had somatoform pain disorder. There was no significant difference between these two groups in terms of demographical properties except martial status. Somatoform pain disorder was found significantly higher in married patients than in single patients. 
Table 4. Comparison of SCLR 90, SSAS, HAM-A, HAM-D scores according to the presence or absence of organic etiology of the pain

\begin{tabular}{lccccc}
\hline $\mathbf{n}$ (\%) & $\begin{array}{c}\text { Organic etiology (+) } \\
\mathbf{n = 2 4} \text { (Mean } \pm \text { SD) }\end{array}$ & $\begin{array}{c}\text { Organic etiology (-) } \\
\mathbf{n = 2 7} \text { (Mean } \pm \text { SD) }\end{array}$ & $\mathbf{f}$ & $\mathbf{t}$ & $\mathbf{p}$ \\
\hline SCL-GSIscore & $1.1 \pm 0.7$ & $1.2 \pm 0.7$ & 0.014 & 0.497 & 0.621 \\
SCL-PSIscore & $46.7 \pm 21.9$ & $49.1 \pm 22.9$ & 0.516 & 0.393 & 0.696 \\
SCL-PSDI score & $1.9 \pm 0.6$ & $2.1 \pm 0.5$ & 0.298 & 1.292 & 0.202 \\
SSAS & $26.1 \pm 10.3$ & $27.8 \pm 8.8$ & 2.739 & 0.644 & 0.523 \\
HAM-A & $15.9 \pm 8.0$ & $18.4 \pm 8.5$ & 0.110 & 1.083 & 0.544 \\
HAM-D & $17.1 \pm 9.8$ & $18.8 \pm 10.2$ & 0.343 & 0.611 & 0.781 \\
\hline
\end{tabular}

n: Number of patients; SD: Standart deviation; SCL: Symptom Screening List; GSI: Global Symptom Index; PSI: Positive Symptom Index; PSDI: Positive Symptom Distress Index; SSAS: Somatosensory Amplification Scale; HAM-D: Hamilton Depression Rating Scale; HAM-A:Hamilton Anxiety Rating Scale.

Table 5. Comparison of sociodemographic properties and scale scores of the patients with and without psychiatric diagnosis

\begin{tabular}{|c|c|c|c|c|c|}
\hline n (\%) & $\begin{array}{l}\text { Psychiatric diagnosis }(+) \\
\qquad(n=38)\end{array}$ & $\begin{array}{l}\text { Psychiatric diagnosis }(-) \\
\qquad(n=13)\end{array}$ & $\mathbf{f}$ & $\mathbf{t}$ & $\mathbf{p}$ \\
\hline \multicolumn{6}{|l|}{ Gender } \\
\hline Female & $30(81.1)$ & $7(18.9)$ & \multirow{2}{*}{-} & \multirow{2}{*}{ - } & \multirow{2}{*}{0.08} \\
\hline Male & $8(57.1)$ & $6(42.9)$ & & & \\
\hline \multicolumn{6}{|l|}{ Martial status } \\
\hline Married & $33(73.3)$ & $12(26.7)$ & \multirow{2}{*}{-} & \multirow{2}{*}{ - } & \multirow{2}{*}{0.598} \\
\hline Single & $5(83.3)$ & $1(16.7)$ & & & \\
\hline \multicolumn{6}{|l|}{ Educational status } \\
\hline Primary education and lower & $16(69.6)$ & $7(30.4)$ & \multirow{2}{*}{-} & \multirow{2}{*}{ - } & \multirow{2}{*}{0.463} \\
\hline Secondary education and higher & $22(78.6)$ & $6(21.4)$ & & & \\
\hline Age (Mean $\pm S D)$ & $40.8 \pm 11.2$ & $38.6 \pm 10.9$ & 0.065 & 0.613 & 0.543 \\
\hline HAM-A (Mean $\pm S D)$ & $19.5 \pm 6.5$ & $10.7 \pm 9.7$ & 3.272 & -3.715 & 0.001 \\
\hline HAM-D (Mean $\pm S D)$ & $20.3 \pm 9.3$ & $11.7 \pm 9.5$ & 0.019 & -2.859 & 0.006 \\
\hline SSAS (Mean \pm SD) & $29.0 \pm 9.6$ & $21.1 \pm 5.9$ & 2.576 & -2.752 & 0.008 \\
\hline SCL-GSI puan (Mean \pm SD) & $1.4 \pm 0.7$ & $0.5 \pm 0.4$ & 8.591 & -3.977 & $<0.001$ \\
\hline SCL-PSI puan (Mean $\pm S D$ ) & $54.5 \pm 20.3$ & $28.9 \pm 16.2$ & 3.664 & -4.108 & $<0.001$ \\
\hline SCL-PSDI puan (Mean \pm SD) & $2.2 \pm 0.6$ & $1.7 \pm 0.5$ & 0.867 & -2.652 & 0.011 \\
\hline
\end{tabular}

n: Number of patients; Sd: Standart deviation; HAM-A: Hamilton Anxiety Rating Scale; HAM-D: Hamilton Depression Rating Scale; SSAS: Somatosensory Amplification Scale; SCL: Symptom Screening List; GSI: Global Symptom Index; PSI: Positive Symptom Index; PSDI: Positive Symptom Distress Index.

There was no significant difference between the levels of depression in chronic pain patients with and without somatoform pain disorder (Table 6).

Chronic pain patients were divided into two groups in terms of presence or absence of anxiety disorders. There was no significant difference between these two groups in terms of demographical properties. Also there was no significant difference between HAM-D and SSAS scores in these patients. Although there was no significant difference in demographic characteristics among participants who were diagnosed with depression, HAM-A scores were significantly higher in these patients. These finding suggested that depression could be a factor that facilitate anxiety in chronic pain patients (Table 7,8 ).

An important relation that we investigated was to reveal the relationship between exaggeration of physical sensations and the level of psychological symptoms. Pearson's correlation analysis indicated that there was a positive and linear correlation be- 
Table 6. Comparison of sociodemographic properties and scale scores of the patients with and without somatoform disorder

\begin{tabular}{|c|c|c|c|c|c|}
\hline n (\%) & $\begin{array}{l}\text { Somatoform disorder ( }+) \\
\qquad(n=19)\end{array}$ & $\begin{array}{l}\text { Somatoform disorder (-) } \\
\qquad(n=32)\end{array}$ & $\mathbf{f}$ & $\mathbf{t}$ & $\mathbf{p}$ \\
\hline \multicolumn{6}{|l|}{ Gender } \\
\hline Female & $16(43.2)$ & $21(56.8)$ & \multirow{2}{*}{-} & \multirow{2}{*}{-} & \multirow{2}{*}{0.150} \\
\hline Male & $3(21.4)$ & $11(78.6)$ & & & \\
\hline \multicolumn{6}{|l|}{ Martial status } \\
\hline Married & $19(42.2)$ & $26(57.8)$ & \multirow{2}{*}{-} & \multirow{2}{*}{-} & \multirow{2}{*}{0.044} \\
\hline Single & $0(0)$ & $6(100)$ & & & \\
\hline \multicolumn{6}{|l|}{ Educational status } \\
\hline Primary education and lower & $9(39.1)$ & $14(60.9)$ & \multirow{2}{*}{-} & \multirow{2}{*}{-} & \multirow{2}{*}{0.802} \\
\hline Secondary education and higher & $10(35.7)$ & $18(64.3)$ & & & \\
\hline Age $($ Mean $\pm S D)$ & $43.3 \pm 10.3$ & $38.5 \pm 11.3$ & 0.069 & -1.522 & 0.134 \\
\hline HAM-A (Mean士SD) & $20.7 \pm 6.9$ & $15.2 \pm 8.4$ & 0.627 & -2.422 & 0.019 \\
\hline HAM-D (Mean士SD) & $21.0 \pm 8.7$ & $16.3 \pm 10.3$ & 1.889 & 1.638 & 0.108 \\
\hline SSAS (Mean \pm SD) & $30.4 \pm 10.6$ & $25.0 \pm 8.2$ & 0.706 & -2.052 & 0.046 \\
\hline
\end{tabular}

n: Number of patients; SD: Standart deviation; HAM-A: Hamilton Anxiety Rating Scale; HAM-D: Hamilton Depression Rating Scale; SSAS: Somatosensory Amplification Scale.

Table 7. Comparison of sociodemographic properties and scale scores of the patients with and without anxiety disorder

\begin{tabular}{|c|c|c|c|c|c|}
\hline n (\%) & $\begin{array}{l}\text { Anxiety disorder (+) } \\
\qquad(n=12)\end{array}$ & $\begin{array}{l}\text { Anxiety disorder (-) } \\
\qquad(n=39)\end{array}$ & $\mathbf{f}$ & $\mathbf{t}$ & $\mathbf{p}$ \\
\hline \multicolumn{6}{|l|}{ Gender } \\
\hline Female & $10(27)$ & $27(73)$ & \multirow{2}{*}{-} & \multirow{2}{*}{-} & \multirow{2}{*}{0.338} \\
\hline Male & $2(14.3)$ & $12(85.7)$ & & & \\
\hline \multicolumn{6}{|l|}{ Martial status } \\
\hline Married & $9(20)$ & $36(80)$ & \multirow{2}{*}{-} & \multirow{2}{*}{-} & \multirow{2}{*}{0.104} \\
\hline Single & $3(50)$ & $3(50)$ & & & \\
\hline \multicolumn{6}{|l|}{ Educational status } \\
\hline Primary education and lower & $3(13)$ & $20(87)$ & \multirow{2}{*}{-} & \multirow{2}{*}{-} & \multirow{2}{*}{0.110} \\
\hline Secondary education and higher & $9(32.1)$ & $19(67.9)$ & & & \\
\hline Age $($ Mean $\pm S D)$ & $36.3 \pm 12.8$ & $41.5 \pm 10.3$ & 0.700 & 1.441 & 0.156 \\
\hline HAM-D (Mean $\pm S D)$ & $15.4 \pm 7.8$ & $18.8 \pm 10.4$ & 1.294 & 1.058 & 0.295 \\
\hline SSAS (Mean \pm SD) & $27.6 \pm 8.6$ & $26.8 \pm 9.8$ & 0.422 & -0.299 & 0.797 \\
\hline
\end{tabular}

n: Number of patients; SD: Standart deviation; HAM-D: Hamilton Depression Rating Scale; SSAS: Somatosensory Amplification Scale.

tween the high level of SSAS scores and the severity of depression and psychological symptoms in the patient (Table 9).

\section{Discussion}

The determined prevalence of psychiatric disorders in our study $(74.5 \%)$, was found similar to studies of Ho et al. (63\%), Polatin et al. (59\%) and Dersh et al.'s (65\%). ${ }^{[21-23]}$ Depression, anxiety and emotional distress are the most frequently assessed negative psychological factors in patients with chronic pain. Recent systematic studies report that chronic pain patients exhibit elevated levels of the factors described as self-reported adverse effects in all indices compared to painless controls. ${ }^{[3,34]}$ Similar to these studies, depressive and somatoform disorders were the most common psychiatric disorders in our study. 
Table 8. Comparison of sociodemographic properties and scale scores of the patients with and without depressive disorder

\begin{tabular}{|c|c|c|c|c|c|}
\hline n (\%) & $\begin{array}{l}\text { Depressive disorder (+) } \\
\qquad(\mathrm{n}=15)\end{array}$ & $\begin{array}{l}\text { Depressive disorder }(-) \\
\qquad(n=36)\end{array}$ & $\mathbf{f}$ & $\mathbf{t}$ & $\mathbf{p}$ \\
\hline \multicolumn{6}{|l|}{ Gender } \\
\hline Female & $11(29.7)$ & $26(70.3)$ & \multirow{2}{*}{-} & \multirow{2}{*}{-} & \multirow{2}{*}{0.935} \\
\hline Male & $4(28.6)$ & $10(71.4)$ & & & \\
\hline \multicolumn{6}{|l|}{ Martial status } \\
\hline Married & $13(28.6)$ & $32(71.1)$ & \multirow{2}{*}{-} & \multirow{2}{*}{-} & \multirow{2}{*}{0.822} \\
\hline Single & $2(33.3)$ & $4(66.7)$ & & & \\
\hline \multicolumn{6}{|l|}{ Educational status } \\
\hline Primary education and lower & $6(26.1)$ & $17(73.9)$ & \multirow{2}{*}{ - } & \multirow{2}{*}{-} & \multirow{2}{*}{0.637} \\
\hline Secondary education and higher & $9(32.1)$ & $19(67.9)$ & & & \\
\hline Age $($ Mean \pm SD) & $41.2 \pm 9.7$ & $39.9 \pm 11.7$ & 0.670 & -0.384 & 0.703 \\
\hline HAM-A (Mean \pm SD) & $22.3 \pm 5.4$ & $15,1 \pm 8.4$ & 1.544 & -1.555 & 0.004 \\
\hline SSAS (Mean \pm SD) & $30.2 \pm 11.5$ & $25.7 \pm 8.3$ & 2.864 & -3.009 & 0.126 \\
\hline
\end{tabular}

n: Number of patients; SD: Standart deviation; HAM-A: Hamilton Anxiety Rating Scale; SSAS: Somatosensory Amplification Scale.

Table 9. Pearson's correlation analysis between SSAS scores and depression, anxiety, and mental symptom severity

\begin{tabular}{|c|c|c|c|c|c|c|}
\hline & HAM-A & HAM-D & SSAS & SCL-GSI & SCL-PSI & SCL-PSDI \\
\hline \multicolumn{7}{|c|}{ HAM-A } \\
\hline$r$ & 1 & 0.657 & 0.440 & 0.487 & 0.484 & 0.416 \\
\hline$p$ & - & $<0.001$ & 0.001 & $<0.001$ & $<0.001$ & 0.002 \\
\hline \multicolumn{7}{|c|}{ HAM-D } \\
\hline$r$ & 0.657 & 1 & 0.308 & 0.463 & 0.393 & 0.443 \\
\hline$p$ & $<0.001$ & - & 0.028 & 0.001 & 0.004 & 0.001 \\
\hline \multicolumn{7}{|l|}{ SASS } \\
\hline$r$ & 0.440 & 0.308 & 1 & 0.672 & 0.591 & 0.539 \\
\hline $\mathrm{p}$ & 0.001 & 0.028 & - & $<0.001$ & $<0.001$ & $<0.001$ \\
\hline \multicolumn{7}{|c|}{ SCL-GSI } \\
\hline$r$ & 0.487 & 0.463 & 0.672 & 1 & 0.921 & 0.755 \\
\hline $\mathrm{p}$ & $<0.001$ & 0.001 & $<0.001$ & - & $<0.001$ & $<0.001$ \\
\hline \multicolumn{7}{|c|}{ SCL-PSI } \\
\hline$r$ & 0.484 & 0.393 & 0.591 & 0.921 & 1 & 0.501 \\
\hline$p$ & $<0.001$ & 0.004 & $<0.001$ & $<0.001$ & - & $<0.001$ \\
\hline \multicolumn{7}{|c|}{ SCL-PSDI } \\
\hline$r$ & 0.416 & 0.443 & 0.539 & 0.755 & 0.501 & 1 \\
\hline $\mathrm{p}$ & 0.002 & 0.001 & $<0.001$ & $<0.001$ & $<0.001$ & - \\
\hline
\end{tabular}

HAM-A: Hamilton Anxiety Rating Scale; HAM-D: Hamilton Depression Rating Scale; SSAS: Somatosensory Amplification Scale; SCL: Symptom Screening List; GSI: Global Symptom Index; PSI: Positive Symptom Index; PSDI: Positive Symptom Distress Index.

The prevalence of chronic pain is higher in individuals diagnosed with depression, and in contrast, the prevalence of depression in chronic painful individuals is also increasing. ${ }^{[35]}$ In our study, comorbid depressive disorder was diagnosed in $29.4 \%$ of patients with chronic pain, which was very low compared to Huang et al.'s study (73\%). [36] In studies using only the DSM criteria, the prevalence of depressive disorder was reported to range from $30 \%$ to $55 \%$. ${ }^{[37]}$ This rate was close to our study. Depression exacerbates the 
pain experience and is an important determinant of pain-related disability. ${ }^{[38]}$ The opposite is true. In the process of diagnosing the severity of depression, symptoms of pain may lead to "criterion contamination".[39] In order to make this distinction, it may be appropriate to assess the compatibility of nonphysical criteria with physical criteria. ${ }^{[40]}$ In our study, there was no significant difference in exaggeration levels of physical sensations in depressed patients when compared to those who were diagnosed with DSM IV. However, a positive correlation was found between the increased depression scores that measured with HAM-D scale and SSAS scores, in chronic pain patients. These results are interpreted as the fact that the level of exaggeration of somatic sensations may increase the severity of depression but not the development of depression. It should be noted that many social factors could cause reactive depressive disorders in pain patients. Semi-structured interviews, such as SCID, provide more benefits for psychiatric diagnostic evaluation in pain patients to eliminate criterion contamination. According to Cassem, the risk of not being aware of depression and not being treated is more important risk factor than the risk of unnecessary treatment. ${ }^{[41]}$ The incidence of depression in clinic-based studies ranges from 1.5\% to $100 \%{ }^{[2]}$ Pain-related factors, such as pain severity, were found as risk factors for depression in various pain disorders and diffuse pain. ${ }^{[14,42,43]}$ In our study, it was also found that the anxiety symptom severity scores were higher in chronic pain patients who had a comorbid depression when compared to those without depression. This was interpreted as anxiety symptoms may be high in patients with chronic pain secondary to depression. The exaggeration level of somatic sensations has not been evaluated as a risk factor in the development of comorbid depression. However, a significant and positive correlation was found between increased SSAS scores and the severity of depressive symptoms and anxiety symptoms in the Spearman correlation analysis.

In the study by Knaster et al., most of the patients completed the criterion of having at least one psychiatric disorder for 12 months. ${ }^{[2]}$ Mood disorder was found in $45 \%$ of patients and anxiety disorder was found in $25 \%$ of patients. Pain levels were correlated with psychiatric disorders. Analyzes in this study showed that anxiety disorders usually begin before the painbut of- ten depressive disorders follow it. Recent studies have reported high comorbidity between chronic pain and anxiety ${ }^{[44]}$ However, our study results showed that the chronic pain patients with depression could be a risk factor for anxiety disorders.

In our study, same as previously reported in Wijeratne et al. ${ }^{[16]}$ and Geerlings et al., ${ }^{[17]}$ there was no difference between patients with or without depression in terms of age, ${ }^{[13]}$ gender, $^{[14,15]}$ or educational level. ${ }^{[13]}$ In one study, it was shown that the chance of achieving acceptable pain control was inversely related with depression. Perception of pain' is the beliefs of patients about the causes of pain, severity, predictability, controllability. ${ }^{[37,45]}$ Negative distorted pain cognitions, which are similar to the well-known cognitive triad of depression, are used to show the distinction between depressive chronic pain patients and non-depressive patients. ${ }^{[46]}$ In patients with chronic pain, there is also low acceptable pain control perception, which leads to hopelessness and depression for the future. This is the 'pain perception' most associated with depression by the regression analysis. ${ }^{[21]}$ In this study, we found that the degree of exaggeration of physical sensations was related to the severity of depressive symptoms. Pain physicians should be cautious about the exaggerated pain perception which may indicate depression. The high SSAS scores in this study can be considered as a factor associated with exaggerated pain perception and may be considered as a risk factor for the development of depression in pain patients. In pain clinics, with structured or semi-structured scales, assesment of exaggerated somatic sensation levels and susceptibilities to somatoform disorders and early pharmacological and psychotherapeutic treatments to these could be beneficial.

The relationship between pain and depression/ anxiety is complicated. Evaluation of the relation between pain and psychiatric disorders has been revealed by some theories. According to consequence theory, depression is expressed as a result of pain and pain comes before depression. But antecedent theory claims the opposite. ${ }^{[2]}$ Fishbain et al. reviewed the literature in terms of this issue and reported that most of the studies has supported the consequence theory. ${ }^{[4]}$ The knowledge of how anxiety, depression and chronic pain are correlated is very important 
because it affects the treatment. Treatment of previously experienced anxiety and depression-related stressful environment and genetic predispositions to chronic pain is harder than treating pain related anxiety or depression. ${ }^{[2]}$

Pain association with specific anxiety and depression disorders has been shown in a recent study. ${ }^{[48]}$ But this relationship is not clear. Anxiety disorder is more severe and more chronic in patients with chronic pain. ${ }^{[49]}$ In a sample with no prior history of depression or anxiety disorder, chronic pain was identified as a significant predictor of the onset of anxiety disorders. ${ }^{[50]}$ Pain and depression probably share neural pathways. ${ }^{[51,52]}$ Genetic factors such as catechol-O-met ${ }^{[53]}$ and seratonin transporter polymorphisims ${ }^{[54]}$ may provide a possible link between pain sensitivity and psychological symptoms. Recent brain imaging studies show depressed patients with impaired pain regulation and altered brain responses. ${ }^{[55]}$ Moreover, the efficacy of some antidepressant drugs for depression, anxiety and pain suggests that the common neural mechanisms are shared. $[2,56,57]$ Correlation between the severity of pain and severity of depression/anxiety symptoms in chronic pain patients was not investigated in our study, but we found a positive correlation between the severity of depression and anxiety symptoms with exaggeration levels of somatosensory symptoms. Exaggeration of a physical sensations such as pain exacerbates the symptoms of anxiety and depression and they positively correlate with each other. This result supports the prediction that pain shares some common neural pathways with depression and anxiety.

\section{Limitation}

The study population was small, which restricts the power of statistical analyzes. The study group consisted of patients who are continuing to the pain outpatient clinic, so there was a bias in patient selection. Our study was conducted with patients with different types of pain. Therefore, the results are still not universal for all chronic pain patients.

\section{Conclusion}

In this study, $74.5 \%$ of the patients, who were consulted to psychiatrist for possible psychiatric disorder, were actually diagnosed. This may be due to the fact that pain physicians' rate of diagnosis were high and their sensitivity was high to the subject. Therefore, we recommend that psychiatric evaluations should be considered in pain clinics. We also think that pain physicians need to be more cautious about the patients, especially those with more than 1 year chronic pain.

In this study, the percentage of psychiatric morbidity in chronic pain patients is higher than in the general population and can be compared with the studies in the west. Somatoform disorders and depressive disorders are the most commonly diagnosed cases. Psychiatric disorders may be associated with highly related with special pain parameters, pain perceptions, and social factors. A better understanding of the anticipatory factors of psychiatric disorders in pain patients will help chronic pain management in the long term. Chronic pain has been correlated with high psychiatric disorder rates. The main focus of clinical trials is depression. In future studies, anxiety may also be of interest. Pain-related psychiatric disorders frequently complicate the treatment protocols, so it is important that they are fully assessed. The use of psychiatric evaluation methods such as SCID provides an understanding of the problem of comorbidity.

Although the mechanisms of the relationship between chronic pain and psychiatric disorders are not fully understood, effective management of both pain intensity and comorbid psychiatric conditions is necessary for the quality of life of patients.

\section{Conflict-of-interest issues regarding the authorship or article: None declared.}

Peer-rewiew: Externally peer-reviewed.

\section{References}

1. Poole H, White S, Blake C, Murphy P, Bramwell R. Depression in chronic pain patients: prevalence and measurement. Pain Pract 2009;9(3):173-80. [CrossRef]

2. Knaster P, Karlsson H, Estlander AM, Kalso E. Psychiatric disorders as assessed with SCID in chronic pain patients: the anxiety disorders precede the onset of pain. Gen Hosp Psychiatry 2012;34(1):46-52. [CrossRef]

3. Burke AL, Mathias JL, Denson LA. Psychological functioning of people living with chronic pain: a meta-analytic review. Br J Clin Psychol 2015;54(3):345-60. [CrossRef]

4. Katon W, Egan K, Miller D. Chronic pain: lifetime psychiatric diagnoses and family history. Am J Psychiatry 1985;142(10):1156-60. [CrossRef] 
5. Merskey H, Lau CL, Russell ES, Brooke RI, James M, Lappano $\mathrm{S}$, et al. Screening for psychiatric morbidity. The pattern of psychological illness and premorbid characteristics in four chronic pain populations. Pain 1987;30:141-57. [CrossRef]

6. Woo AK. Depression and anxiety in pain. Reviews in Pain 2010;4(1):8-12. [CrossRef]

7. Hung $\mathrm{Cl}$, Liu CY, Fu TS. Depression: An important factor associated with disability among patients with chronic low back pain. Int J Psychiatry Med 2015;49(3):187-98. [CrossRef]

8. Ross C, Juraskova I, Lee H, Parkitny L, Stanton TR, Moseley $\mathrm{GL}$, et al. Psychological distress mediates the relationship between pain and disability in hand or wrist fractures. J Pain 2015;16(9):836-43. [CrossRef]

9. Kenardy J, Heron-Delaney M, Warren J, Brown EA. Effect of mental health on long-term disability after a road traffic crash: results from the UQ SuPPORT study. Arch Phys Med Rehabil 2015;96(3):410-7. [CrossRef]

10. Smith D, Wilkie R, Uthman O, Jordan JL, McBeth J. Chronic pain and mortality: a systematic review. PLoS One 2014;9(6):e99048. [CrossRef]

11. Hassett AL, Aquino JK, Ilgen MA. The risk of suicide mortality in chronic pain patients. Curr Pain Headache Rep 2014;18(8):436. [CrossRef]

12. Ilgen MA, Kleinberg $F$, Ignacio RV, Bohnert AS, Valenstein $\mathrm{M}, \mathrm{McC}$ arthy JF, et al. Noncancer pain conditions and risk of suicide. JAMA Psychiatry 2013;70(7):692-7. [CrossRef]

13. Réthelyi JM, Berghammer R, Kopp MS. Comorbidity of pain-associated disability and depressive symptoms in connection with sociodemographic variables: results from a cross-sectional epidemiological survey in Hungary. Pain 2001;93(2):115-21. [CrossRef]

14. Haley WE, Turner JA, Romano JM. Depression in chronic pain patients: relation to pain, activity, and sex differences. Pain 1985;23(4):337-43. [CrossRef]

15. Meana M. The meeting of pain and depression: Comorbidity in women. Can J Psychiatry 1998;43(9):893-9. [CrossRef]

16. Wijeratne C, Shome S, Hickie I, Koschera A. An age-based comparison of chronic pain clinic patients. Int J Geriatr Psychiatry 2001;16(5):477-83. [CrossRef]

17. Geerlings SW, Twisk JW, Beekman AT, Deeg DJ, van Tilburg W. Longitudinal relationship between pain and depression in older adults: sex, age and physical disability. Soc Psychiatry Psychiatr Epidemiol 2002;37(1):23-30. [CrossRef]

18. Granot M, Ferber SG. The roles of pain catastrophizing and anxiety in the prediction of postoperative pain intensity: a prospective study. Clin J Pain 2005;21(5):439-45. [CrossRef]

19. Wittchen HU, Kessler RC, Beesdo K, Krause P, Hofler M, Hoyer J. Generalized anxiety and depression in primary care: prevalence, recognition, and management. J Clin Psychiatry 2002;63(Suppl 8):24-34.

20. Beesdo K, Hartford J, Russell J, Spann M, Ball S, Wittchen HU. The short- and long-term effect of duloxetine on painful physical symptoms in patients with generalized anxiety disorder: results from three clinical trials. J Anxiety Disord 2009;23(8):1064-71. [CrossRef]

21. Ho PT, Li CF, Ng YK, Tsui SL, Ng KF. Prevalence of and factors associated with psychiatric morbidity in chronic pain patients. J Psychosom Res 2011;70(6):541-7. [CrossRef]

22. Polatin PB, Kinney RK, Gatchel RJ, Lillo E, Mayer TG. Psychiatric illness and chronic low-back pain. The mind and the spine--which goes first? Spine (Phila Pa 1976) 1993;18(1):66-71. [CrossRef]

23. Dersh J, Gatchel RJ, Polatin P, Mayer T. Prevalence of psychiatric disorders in patients with chronic work-related musculoskeletal pain disability. J Occup Environ Med 2002;44(5):459-68. [CrossRef]

24. Gerrits MM, van Marwijk HW, van Oppen $P$, van der Horst $H$, Penninx BW. Longitudinal association between pain, and depression and anxiety over four years. J Psychosom Res 2015;78(1):64-70. [CrossRef]

25. Gerrits MM, van Oppen P, Leone SS, van Marwijk HW, van der Horst $\mathrm{H}$, Penninx BW. Pain, not chronic disease, is associated with the recurrence of depressive and anxiety disorders. BMC Psychiatry 2014;14:187. [CrossRef]

26. Derogatis LR. SCL-90-R, Administration, Scoring \& Procedures Manual-I for the Revised Version. Baltimore, MD: John Hopkins Univ, School of Medicine Clinical Psychometrics Unit; 1977.

27. Dağ I. Belirti Tarama Listesi (Scl-90-R)'nin Üniversite Öğrencileri için güvenirliği ve geçerliği. Türk Psikiyatri Dergisi 1991;2:5-12.

28. Hamilton M. A rating scale for depression. J Neurol Neurosurg Psychiatry 1960;23:56-62. [CrossRef]

29. Akdemir A, Türkcapar H, Orsel SD, Demirergi N, Dag I, Ozbay $\mathrm{MH}$. Reliability and validity of the Turkish version of the Hamilton Depression Rating Scale. Compr Psychiatry 2001;42(2):161-5. [CrossRef]

30. Hamilton $\mathrm{M}$. The assessment of anxiety states by rating. $\mathrm{Br}$ J Med Psychol 1959;32(1):50-5. [CrossRef]

31. Yazıcı M, Demir B, Tanrıverdi N, Karaagaoğlu E, Yolac P. Hamilton Anxiety Rating Scale: Interrater Reliabilty and Validity Study. Türk Psikiyatri Dergisi 1998;9(2):114-7.

32. Barsky AJ, Wyshak G, Klerman GL. The somatosensory amplification scale and its relationship to hypochondriasis. J Psychiatr Res 1990;24(4):323-34. [CrossRef]

33. Gulec H, Sayar K. Reliability and validity of the Turkish form of the Somatosensory Amplification Scale. Psychiatry Clin Neurosci 2007;61(1):25-30. [CrossRef]

34. Howe CQ, Robinson JP, Sullivan MD. Psychiatric and Psychological Perspectives on Chronic Pain. Phys Med Rehabil Clin N Am 2015;26(2):283-300. [CrossRef]

35. Adams LM, Turk DC. Psychosocial factors and central sensistivity syndromes. Curr Rheumatol Rev 2015;11(2):96108. [CrossRef]

36. Huang TY, Lee Y, Chong MY. Psychological distress and help-seeking in patients with chronic pain. Chang Gung Med J 2005;28(4):247-53.

37. Banks $S$, Kerns R. Explaining high rates of depression in chronic pain: A diathesis-stress framework. Psychological Bulletin 1996;119(1):95-110. [CrossRef]

38. Hall AM, Kamper SJ, Maher CG, Latimer J, Ferreira ML, Nicholas MK. Symptoms of depression and stress mediate the effect of pain on disability. Pain 2011;152(5):1044-51. [CrossRef] 
39. C. Williams A. Depression in Chronic Pain: Mistaken Models, Missed Opportunities. Behaviour Therapy 1998;27:6180. [CrossRef]

40. Wilson KG, Mikail SF, D’Eon JL, Minns JE. Alternative diagnostic criteria for major depressive disorder in patients with chronic pain. Pain 2001;91(3):227-34. [CrossRef]

41. Cassem EH. Depression and anxiety secondary to medical illness. Psychiatr Clin North Am 1990;13(4):597-612. [CrossRef]

42. Dworkin SF, Von Korff M, LeResche L. Multiple pains and psychiatric disturbance. An epidemiologic investigation. Arch Gen Psychiatry 1990;47(3):239-44. [CrossRef]

43. Kato K, Sullivan PF, Evengard B, Pedersen NL. Chronic widespread pain and its comorbidities: a population-based study. Arch Intern Med 2006;166(15):1649-54. [CrossRef]

44. Katz J, Pagé MG, Fashler S, Rosenbloom BM, Asmundson GJG. Chronic pain and the anxiety disorders: epidemiology, mechanisms and models of comorbidity, and treatment. In: Marchand S, Saravane D, Gaumond I, editors. Mental health and pain: somatic and psychiatric components of pain in mental health. New York, Ny, US: SpringerVerlag Publishing; 2014. p.119-55. [CrossRef]

45. Campbell LC, Clauw DJ, Keefe FJ. Persistent pain and depression: a biopsychosocial perspective. Biol Psychiatry 2003;54(3):399-409. [CrossRef]

46. Stroud MW, Thorn BE, Jensen MP, Boothby JL. The relation between pain beliefs, negative thoughts, and psychosocial functioning in chronic pain patients. Pain 2000;84(23):347-52. [CrossRef]

47. Fishbain DA, Cutler R, Rosomoff HL, Rosomoff RS. Chronic pain-associated depression: antecedent or consequence of chronic pain? A review. Clin J Pain 1997;13(2):116-37.

48. Beesdo K, Jacobi F, Hoyer J, Low NC, Hofler M, Wittchen HU. Pain associated with specific anxiety and depressive disorders in a nationally representative population sample. Soc
Psychiatry Psychiatr Epidemiol 2010;45(1):89-104. [CrossRef]

49. Gerrits MMJG, Vogelzangs N, van Oppen P, van Marwijk HW, van der Horst $\mathrm{H}$, Penninx BW. Impact of pain on the course of depressive and anxiety disorders. Pain 2012;153(2):42936. [CrossRef]

50. Gerrits MM, van Oppen P, van Marwijk HW, Penninx BW, van der Horst HE. Pain and the onset of depressive and anxiety disorders. Pain 2014;155(1):53-9. [CrossRef]

51. Benarroch EE. Descending monoaminergic pain modulation: bidirectional control and clinical relevance. Neurology 2008;71(3):217-21. [CrossRef]

52. Mason P. Deconstructing endogenous pain modulations. J Neurophysiol 2005;94(3):1659-63. [CrossRef]

53. Zubieta JK, Heitzeg MM, Smith YR, Bueller JA, Xu K, Xu $Y$, et al. COMT val158met genotype affects mu-opioid neurotransmitter responses to a pain stressor. Science 2003;299(5610):1240-3. [CrossRef]

54. Caspi A, Sugden K, Moffitt TE, Taylor A, Craig IW, Harrington $\mathrm{H}$, et al. Influence of life stress on depression: moderation by a polymorphism in the 5 -HTT gene. Science 2003;301(5631):386-9. [CrossRef]

55. Strigo IA, Simmons AN, Matthews SC, Craig AD, Paulus MP. Association of major depressive disorder with altered functional brain response during anticipation and processing of heat pain. Arch Gen Psychiatry 2008;65(11):1275-84.

56. Nekovarova T, Yamamotova A, Vales K, Stuchlik A, Fricova J, Rokyta R. Common mechanisms of pain and depression: are antidepressants also analgesics? Frontiers in Behavioral Neuroscience 2014;8:99. [CrossRef]

57. Finnerup NB, Attal N, Haroutounian S, McNicol E, Baron R, Dworkin $\mathrm{RH}$, et al. Pharmacotherapy for neuropathic pain in adults: a systematic review and meta-analysis. Lancet Neurology 2015;14(2):162-73. [CrossRef] 